\title{
Is Online Pregnant School Training Effective in Reducing the Anxiety of Pregnant Women and Their Partners During the COVID-19 Pandemic?
}

\section{COViD-19 Pandemi Döneminde Online Yapılan Gebe Okulu Eğitimleri Gebelerin ve Eşlerinin Anksiyetelerini Azaltmada Etkili Midir?}

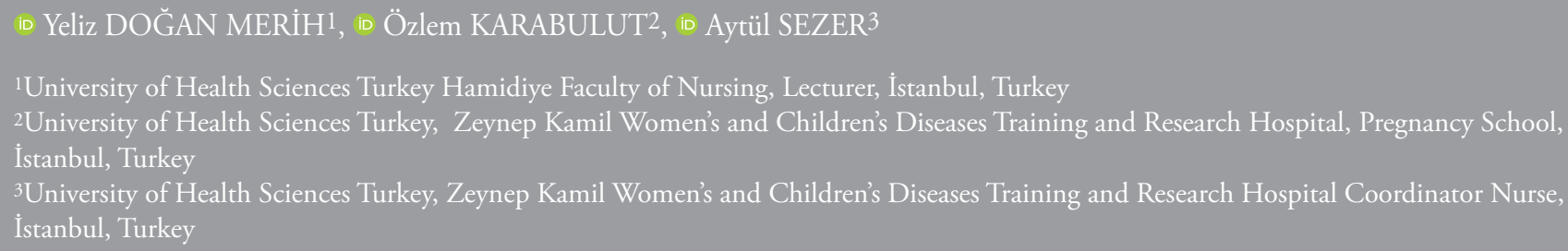

\section{ABSTRACT}

Objective: The aim of this study was to determine the views of pregnant women and their spouses on the coronavirus disease-19 (COVID-19) pandemic process, to support pregnant women and their spouses through online pregnancy school training, and to decrease their anxiety levels.

Methods: The universe of this semi-experimental study with pre-and post-training model consisted of all pregnant women presenting at the pregnancy monitoring service of an Obstetrics and Pediatrics Training and Research Hospital in the Anatolian side of Istanbul between April and May 2020. 90 people (45 pregnant women and 45 spouses) who met inclusion criteria were included in the study. Data were collected using a questionnaire including the demographic of the participants as well as their views on the COVID-19 process and the Beck Anxiety Inventory. Study data were evaluated using percentages, mean values, the chi-square test, and one-way ANOVA.

Results: In the study, the anxiety scores in both groups were found to decrease (the pre-education score of the mothers is $9.05 \pm 7.29$ and the post-education score is $5.56 \pm 5.38$, the pre-education score of the fathers is $3.13 \pm 3.60$ and the post-education score is $2.02 \pm 2.49$ ) significantly after training $(\mathrm{p}<0.05)$.

Conclusion: Online pregnancy school for pregnant women and their spouses during the COVID-19 pandemic period was effective in reducing the anxiety levels of the parents.

Keywords: Anxiety, COVID-19 training, pregnancy, pandemic

\section{ÖZ}

Amaç: Çalışma, pandemi döneminde gebelerin ve eşlerinin koronavirüs hastalığı-19 (COVID-19) pandemi sürecine yönelik görüşlerini belirlemek, online yapılan gebe okulu eğitimleri ile gebe ve eşlerini destelemek, anksiyete oranlarını azaltmak amacıyla gerçekleştirilmiştir.

Yöntemler: Eğitim öncesi-sonrası modelli yarı deneysel çalışmanın evrenini, İstanbul ili Anadolu yakasında bulunan kadın ve çocuk hastalıkları eğitim ve araştırma hastanesinin gebe izlemine NisanMayıs 2020 tarihleri arasında başvuran gebeler oluşturmuştur. Örnekleme alınma kriterlerine uyan 90 kişi (45 gebe ve 45 eş) dahil edilmiştir. Veriler, katılımcıların demografik, COVID-19 sürecine yönelik görüşlerinin yer aldığı anket formu ve Beck Ankisyete Ölçeği ile toplanmıştır. Araştırmadan elde edilen veriler, yüzde, ortalama, ki-kare testi, t-testi ve one-way ANOVA testleri ile kullanılmıştır.

Bulgular: Çalışmada her iki grupta da eğitim sonrası anksiyete puanlarının düştüğü (annelerin eğitim öncesi puanı 9,05 $\pm 7,29$ ve eğitim sonrası puanı $5,56 \pm 5,38$, babaların eğitim öncesi puanı $3,13 \pm 3,60$ ve eğitim sonrası puan $2,02 \pm 2,49$ ) ve aradaki farkın istatistiksel açıdan anlamlı olduğu belirlenmiştir $(\mathrm{p}<0,05)$.

Sonuç: COVID-19 pandemi döneminde gebe ve eşlerine uygulanan online gebe okulunun anne-baba adaylarının anksiyete düzeylerini azaltmada etkili olduğu belirlenmiştir.

Anahtar Sözcükler: Ankisyete, COVİD-19, eğitim, gebelik, pandemi

*This work was supported by Gilead Sciences.

Address for Correspondence: Yeliz DOǦAN MERiH, University of Health Sciences Turkey, Zeynep Kamil Women's and Children's Diseases Training and Research Hospital, Pregnancy School, istanbul, Turkey, University of Health Sciences Turkey Hamidiye Faculty of Nursing, Health Care Services Manager, istanbul, Turkey E-mail: yelizmrh@gmail.com ORCID ID: orcid.org/0000-0002-6112-0642

Cite this article as: Doğan Merih Y, Karabulut Ö, Sezer A. Is Online Pregnant School Training Effective in Reducing the Anxiety of Pregnant Women and Their Partners During the COVID-19 Pandemic?. Bezmialem Science. 2021;9(Supplement 1):13-24. 


\section{Introduction}

Although pregnancy is a physiological process for women, it is a period in which important biological and psychosocial changes occur, and the risk of encountering factors that may cause stress and anxiety is high (1). Women perceive pregnancy as a source of joy, satisfaction, maturity, self-realization, and happiness, as well as a period in which negative psychological emotions such as stress, anxiety, anxious anticipation, and overloading can be experienced (2).

Anxiety is a disturbing feeling which is life-threatening or perceived to be life-threatening and expressed with words such as apprehension and worry. It is an emotional situation experienced in the face of the possibility of danger from the internal or external world or any situation perceived and interpreted as dangerous by the person (3). Most of the physiological conditions seen in pregnancy are very similar to anxiety symptoms, so anxiety disorders are masked in pregnant women. Clinicians need to be careful about this (4). The rates of depression and anxiety disorders in pregnancy reported in studies conducted in the last 30 years vary, but the rates generally reported are higher than the rates in the general population (5-7). Previous studies found that the frequency of depression and depressive symptoms during pregnancy varies between $5-51 \%$ (8). In one of the few studies on this subject in Turkey, according to the Beck Depression Inventory (limit 17 and above), the incidence of depressive symptoms was found between $10-15 \%$ (9).

Each woman's reaction to pregnancy varies according to her mental, socioeconomic, and cultural background. A pregnancy which increases the love between spouses and strengthens the foundations of marriage leads to hormonal changes that induces psychological changes in women (10). As a new stage in human life, parenting is a stressful situation for spouses. When this stress is combined with the possibility that everything will not go well during pregnancy, it creates a heavy burden for parents, thus affecting family and public health (10).

Since many of the symptoms seen during pregnancy are similar to anxiety symptoms, the anxiety may be masked (11). Since this situation creates a problem also for Turkey, comprehensive training that includes information about pregnancy, birth, and puerperium and support should be provided (12). Pregnancy education classes, which have an important place today, make it easier for parents to adapt to the periods of pregnancy, birth, and puerperium, prepare couples for the parenting process, increase the harmony between spouses, and reduce anxiety $(13,14)$. In addition, women who get training during pregnancy, childbirth, and postpartum periods perceive a higher quality of life after pregnancy and postpartum, learn to cope with problems such as fear of childbirth and labor pain, and experience less stress related to pregnancy (15).

There are many factors affecting the anxiety levels of expectant mothers and fathers during pregnancy. In many studies, it has been shown that depression and anxiety during pregnancy can be related to age, marital status, number of children, education level, smoking, alcohol and substance use, the trimester of pregnancy, whether the pregnancy is voluntary, sociodemographic characteristics, and previous illnesses and crises (16-19).

Coronavirus disease-19 (COVID-19) has gradually spread around the world and turned into a pandemic. Its rapid spread, lack of a cure, and its fatality increase the effect of the disease. An increased sensitivity has not been reported in pregnant women compared to the general population. However, because pregnant women are more susceptible to diseases than non-pregnant women, their morbidity and mortality are higher, and similar viruses like severe acute respiratory syndrome-CoV (SARS$\mathrm{CoV}$ ) and Middle East respiratory syndrome-CoV (MERS$\mathrm{CoV}$ ) infections caused high mortality rates the management of suspicious or infected pregnant women should be done by a competent multidisciplinary team. Limited information is available on pregnant women and management is like nonpregnant women for now. Fetal distress and premature birth have been observed in some pregnant women. There is no evidence yet that it passes from mother to baby. In pregnancy and delivery management, isolation under appropriate conditions, aggressive infection control, early mechanical ventilation in progressive respiratory problems, oxygen therapy, avoiding excess fluid, and strict fetal, and uterine monitoring are necessary (20).

The COVID-19 pandemic caused an increase in anxiety rates in pregnant women and their families, especially in the risky group, as in the whole society. In this pandemic period where many physical, social, and psychological changes have been experienced, the effective use of infection control measures for the protection of physical and mental health, as well as the development of solution-oriented approaches, information sharing, and individual coping methods are of great importance.

Midwives and nurses are the closest healthcare personnel who determine the risk factors that may occur during pregnancy, create self-confidence in the mother with their knowledge and experience, provide awareness in maternal-fetal interaction, support the preparation of the pregnant for motherhood, help regulate family relations, and provide consultancy to women (2123). Several studies indicated that pregnant women who have received antenatal training use less medication, have less anxiety, and have less depression in the postpartum period. According to the circular issued in 2014 by the Ministry of Health Public Health Agency of Turkey, to be informed during pregnancy is a right of motherhood. In this context, they recommended that pregnant information schools initiated as soon as possible in institutions affiliated with the Public Health Authority and the Association of Public Hospitals. With this circular, pregnancy schools have become widespread in Turkey $(24,25)$. We believe that evaluating the contributions of the pregnancy school and determining women's opinions and suggestions about this training will contribute to those who plan to implement pregnancy schools.

During the pandemic, many processes were suspended due to the importance of home isolation. Pregnancy schools are among the suspended services. We planned our study considering the necessity of pregnancy schools and created live online pregnancy 
schools. Pregnant women and their spouses were provided with pregnancy school services in safe home conditions. We designed a semi-experimental study with a pre-and post-training model without a control group to evaluate the effect of online pregnancy school on anxiety levels during the COVID-19 pandemic.

\section{The Hypothesis of the Study}

H0: Online pregnancy school training do not have a positive effect on reducing the anxiety rates of pregnant women and their partners.

H1: Online pregnancy school training has a positive effect on reducing the anxiety rates of pregnant women and their spouses.

\section{Method}

This study was performed between April and May 2020 at an Obstetrics and Pediatrics Training and Research Hospital in the Anatolian side of Istanbul.

\section{Sample and Universe}

The study universe consisted of pregnant women who applied to the pregnant follow-up clinic of the hospital during the study period. The study sample included pregnant women and their partners who were between 20-45 years old, whose pregnancy week was 30 or above, who could speak and understand Turkish, and who volunteered to participate in the live online pregnancy school. The study sample consisted of 45 pregnant women and their 45 partners.

\section{Tools for Data Collection}

Data were collected using a questionnaire containing demographic, individual, and obstetric characteristics of the participants, their opinions about the COVID-19 process, and the beck anxiety scale.

Pregnant data form: Pregnant data form which was prepared by researchers in accordance with the literature included 25 questions about socio demography (age, year of marriage, education, employment, economic status, family type, having a chronic illness) $(1,2,10,15,16)$, obstetric history (pregnancy week, whether the pregnancy was wanted, route of conception, problems in pregnancy, training about pregnancy, opinions about pregnancy schools) $(1,2,10,15,16)$, opinions about the COVID-19 pandemic, and evaluation of the training.

Spouse data form: Spouse data form which was prepared by researchers in accordance with the literature included 20 questions about socio demography (age, marriage year, education, employment, economic status, family type, having a chronic disease) (1,2,10,15,16), opinions about pregnancy school, opinions about the COVID-19 pandemic, and evaluation of training they received.

Beck anxiety inventory (BAI): This scale was given to pregnant women and their spouses at the first interview and at the end of the training. The scale was developed by Beck et al. (1988) and adapted to Turkish by Ulusoy et al. (26). The scale has been found to have sufficient reliability and validity (25). BAI evaluates the frequency of anxiety symptoms experienced by the individual. It is a self-rating scale, consisting of 21 items scored between 0 and 3. Questions are asked to understand the level of disturbance caused by distress feelings last week. The score range is between 0 to 63 . The higher the score obtained from the scale, the more severe the anxiety experienced by the individual. For Beck Anxiety Inventory 0-7 points indicate minimal anxiety, 8-15 points indicate mild anxiety, $16-25$ points indicate moderate anxiety, and 26-63 points indicate severe anxiety (26). Permission to use the scale was obtained.

\section{Content of Online Birth and Baby Preparation Training}

Scope of Training: The training was planned as 6 sessions of online meeting and training program (a 6-day program was designed, all sessions were attended by pregnant women and their spouses together).

Training hours: Each session was 3 hours, with 10 minutes breaks in between.

Training program: The training program was shared with the participants in advance (birth preparation training in the $1^{\text {st }}$ and $2^{\text {nd }}$ sessions, preparation to breastfeeding training in the $3^{\text {rd }}$ session, baby care training in the $4^{\text {th }}$ session, adaptation to the postpartum process, parenting process, reproductive health and sexuality, family planning and evaluation of the whole training program and opinions and suggestions in the $5^{\text {th }}$ and $6^{\text {th }}$ sessions). Online Birth Preparation training was enriched with supportive meditation, imagination, presentations, videos, games, painting works that support the expression of emotions, and drama games for expectant mothers and fathers.

Educator: Training was provided by Zeynep Kamil Hospital Pregnancy School Educator Midwife Özlem Karabulut.

\section{Data Collection}

The pregnant women who came to the pregnant followup department of the hospital for control and who met the sampling criteria were informed about the study, the pregnant women who agreed to participate in the study were informed about the online education process, and their consents were obtained.

The pregnant women and their spouses who would participate in the live online (zoom) pregnancy school training group were informed by the researchers about the content and program.

On the first day of training, the relevant data forms were first sent to the participants by e-mail and they were asked to fill them out.

After the data forms were filled, training including pregnancy, birth, postnatal process, and baby care processes were given by the maternity school educator with the interactive participation of the participants. At the end of the training, feedback was received. 
After the completion of the training, the training evaluation form and Beck Anxiety form were given again and the process was evaluated.

\section{Ethical Aspect of the Research}

Institutional permission from the institution where the research was conducted and approval from the ethics committee was obtained. Written consent was taken after the pregnant women participating in the study and their spouses were informed about the purpose of the study and it was explained that the obtained information would only be used for this study.

\section{Analysis of Data}

The socio-demographic and obstetric characteristics of the pregnant women participating in the study were evaluated using the percentage, the chi-square test was used to test the relationships between categorical variables, t-test for independent groups and the One-Way ANOVA parametric test were used to analyze normally distributed data. SPSS 15 package program was used in the analysis of the data and the level of significance was taken as 0.05 .

\section{Results}

The mean age of the pregnant women participating in the study was $29.44 \pm 4.43$, the mean age of the spouses was $32.58 \pm 5.37$, and the duration of marriage was $3.01 \pm 1.91$ years. Most of the pregnant women $(97.8 \%)$ received high school or higher education, $73.4 \%$ were employed, $60.0 \%$ evaluated their income as moderate, $77.8 \%$ did not have a chronic disease, $84.4 \% \mathrm{did}$ not smoke, $73.3 \%$ did not use alcohol, and $71.2 \%$ their mental state as good. All of the spouses (100.0\%) received high school or higher education, most (95.6\%) worked, $51.1 \%$ evaluated their income as moderate, $88.9 \%$ did not have a chronic disease, $77.8 \%$ did not smoke, $86.7 \%$ did not use alcohol, $86.7 \%$ evaluated their mental state as good. $93.4 \%$ of the participants had social security, and most (97.8\%) had a nuclear family structure (Table 1).

The obstetric characteristics of pregnant women participating in the study are given in Table 2. Among the pregnant women, $73.3 \%$ were primiparous, $93.4 \%$ got pregnant voluntarily, $88.9 \%$ had their pregnancy without any problems, most (91.2\%) attended to regular pregnancy control visits, $37.8 \%$ had received information during a previous pregnancy, and in $44.4 \%$ primary source of information was TV and internet.

Participants' views on the functioning of the pregnancy school are given in Table 3. Most of the participants $(77.8 \%$ of the pregnant women, $82.2 \%$ of the fathers) found themselves competent in pregnancy, childbirth, and puerperium, they had attended a limited number of pregnant school training before and stated that it was not good to suspend the birth preparation training (62.2\% of the pregnant women, $71.1 \%$ of the fathers). They mostly wanted preparatory education to be delivered online as remote education $(95.6 \%$ of the pregnant women, and $100.0 \%$ of the fathers).
Table 1. Distribution of participants by demographic and health histories

\begin{tabular}{|c|c|c|c|c|c|}
\hline \multirow{2}{*}{ Individual features } & & \multicolumn{2}{|c|}{ Mother } & \multicolumn{2}{|c|}{ Father } \\
\hline & & $\mathrm{N}$ & $\%$ & $\mathrm{~N}$ & $\%$ \\
\hline \multirow{4}{*}{ Age distribution } & $20-25$ years & 7 & 15.5 & 2 & 4.4 \\
\hline & 26-31 years & 24 & 53.3 & 18 & 40.0 \\
\hline & $32-37$ years & 12 & 26.6 & 21 & 46.6 \\
\hline & $38-43$ years & 1 & 2.2 & 4 & 8.8 \\
\hline \multirow{2}{*}{ Education status } & $\begin{array}{l}\text { Primary } \\
\text { school }\end{array}$ & 1 & 2.2 & - & - \\
\hline & $\begin{array}{l}\text { High school } \\
\text { and above }\end{array}$ & 44 & 97.8 & 45 & 100.0 \\
\hline \multirow{2}{*}{ Employment status } & Employed & 33 & 73.4 & 43 & 95.6 \\
\hline & Unemployed & 12 & 26.6 & 2 & 4.4 \\
\hline \multirow{3}{*}{ Monthly income } & Good & 16 & 25.6 & 20 & 44.4 \\
\hline & Moderate & 27 & 60.0 & 23 & 51.1 \\
\hline & Bad & 2 & 4.4 & 2 & 4.4 \\
\hline \multirow{2}{*}{\multicolumn{2}{|c|}{$\begin{array}{l}\text { Health history } \\
\text { N }\end{array}$}} & \multicolumn{2}{|c|}{ Mother } & \multicolumn{2}{|c|}{ Father } \\
\hline & & $\%$ & $\mathbf{N}$ & $\%$ & \\
\hline \multirow{2}{*}{ Chronic disease } & Yes & 10 & 22.2 & 5 & 11.1 \\
\hline & No & 35 & 77.8 & 40 & 88.9 \\
\hline \multirow{3}{*}{ Smoking } & Yes & 2 & 4.4 & 10 & 22.2 \\
\hline & No & 38 & 84.4 & 35 & 77.8 \\
\hline & $\begin{array}{l}\text { Stopped due } \\
\text { to pregnancy }\end{array}$ & 5 & 11.1 & - & - \\
\hline \multirow{3}{*}{ Alcohol use } & Yes & - & - & 6 & 13.3 \\
\hline & No & 33 & 73.3 & 39 & 86.7 \\
\hline & $\begin{array}{l}\text { Stopped due } \\
\text { to pregnancy }\end{array}$ & 12 & 26.7 & - & - \\
\hline \multirow{3}{*}{$\begin{array}{l}\text { Mental self- } \\
\text { evaluation }\end{array}$} & Good & 32 & 71.2 & 39 & 86.7 \\
\hline & Moderate & 2 & 4.4 & 6 & 13.3 \\
\hline & Bad & 11 & 24.4 & - & - \\
\hline \multicolumn{2}{|l|}{ Total } & 45 & 100.0 & 45 & 100.0 \\
\hline
\end{tabular}

Topics that the participants want to be included in the online birth preparation training is given in Table 4. Both the pregnant women and their spouses wanted all issues regarding the pregnancy process and baby care to be included in their training.

Table 5 includes the opinions of the participants about COVID-19 infection control measures. Participants generally knew COVID-19 infection control measures $(93.3 \%$ pregnant women, $93.3 \%$ fathers), applied protection measures at high rates (97.8\% of the pregnant women, $93.3 \%$ of the fathers), and could apply social distance and isolation rules at home conditions (77.8\% of the pregnant women, $80.0 \%$ of the fathers).

The concerns of the participants during the COVID-19 pandemic are evaluated in Table 6. Pregnant women stated that during the pandemic period their concerns were the absence of spouse or a relative at birth $(86.2 \%)$, the risk of contracting COVID-19 infection from healthcare workers $(82.2 \%)$ and experiencing pain with a mask (82.2\%). Concerns of the fathers 
Table 2. Distribution of mothers by obstetric characteristics

\begin{tabular}{|c|c|c|c|}
\hline \multicolumn{2}{|l|}{ Features } & $\mathrm{N}$ & $\%$ \\
\hline \multirow{2}{*}{ Number of pregnancies } & 1 & 33 & 73.3 \\
\hline & $2-3$ & 12 & 26.7 \\
\hline \multirow{2}{*}{$\begin{array}{l}\text { Was the latest pregnancy } \\
\text { wanted? }\end{array}$} & Yes & 42 & 93.4 \\
\hline & No & 13 & 6.6 \\
\hline \multirow{2}{*}{$\begin{array}{l}\text { Was there a problem with the } \\
\text { latest pregnancy? }\end{array}$} & Yes & 5 & 11.1 \\
\hline & No & 40 & 88.9 \\
\hline \multirow{2}{*}{$\begin{array}{l}\text { Attended to routine controls } \\
\text { during the latest pregnancy }\end{array}$} & Yes & 41 & 91.2 \\
\hline & No & 4 & 8.8 \\
\hline \multirow{2}{*}{$\begin{array}{l}\text { Got training/information } \\
\text { during pregnancy }\end{array}$} & Yes & 17 & 37.8 \\
\hline & No & 28 & 62.2 \\
\hline \multirow{5}{*}{$\begin{array}{l}\text { Source of information/training } \\
\text { about post-natal care in } \\
\text { pregnancy }\end{array}$} & TV, internet & 20 & 44.4 \\
\hline & Relative, friend & 10 & 32.2 \\
\hline & Doctor & 5 & 11.1 \\
\hline & Nurse, midwife & 2 & 4.4 \\
\hline & Book & 11 & 24.4 \\
\hline \multicolumn{2}{|l|}{ Total } & 45 & 100.0 \\
\hline
\end{tabular}

Table 3. Opinions of the participants about pregnancy school

\begin{tabular}{|c|c|c|c|c|c|}
\hline \multirow{2}{*}{ Individual characteristics } & & \multicolumn{2}{|c|}{ Mother } & \multicolumn{2}{|c|}{ Father } \\
\hline & & $\mathrm{N}$ & $\%$ & $\mathrm{~N}$ & $\%$ \\
\hline \multirow{2}{*}{$\begin{array}{l}\text { Feels sufficient about } \\
\text { pregnancy, childbirth, } \\
\text { and puerperium }\end{array}$} & Yes & 10 & 32.2 & 8 & 17.8 \\
\hline & No & 35 & 77.8 & 37 & 82.2 \\
\hline \multirow{2}{*}{$\begin{array}{l}\text { Previously attended } \\
\text { pregnancy training }\end{array}$} & Yes & 9 & 20.0 & 6 & 13.3 \\
\hline & No & 39 & 86.7 & 36 & 80.0 \\
\hline \multirow{3}{*}{$\begin{array}{l}\text { Opinion about the } \\
\text { suspension of birth } \\
\text { preparation training }\end{array}$} & Good & 7 & 15.6 & 2 & 4.4 \\
\hline & Indecisive & 10 & 22.2 & 11 & 24.4 \\
\hline & Bad & 28 & 62.2 & 32 & 71.1 \\
\hline \multirow{2}{*}{$\begin{array}{l}\text { Requesting that the } \\
\text { childbirth preparation } \\
\text { training be given online }\end{array}$} & Yes & 43 & 95.6 & 45 & 100.0 \\
\hline & No & 2 & 4.4 & - & - \\
\hline Total & & 45 & 100.0 & 45 & 100.0 \\
\hline
\end{tabular}

were not being with their wives during birth $(82.2 \%)$, getting COVID-19 infection from another patient $(80 \%)$, or from healthcare workers $(75.6 \%)$.

Opinions of the pregnant women and their spouses about the education were taken after the live online pregnancy school training (Table 7). $88.9 \%$ of the pregnant women and all of the spouses were very satisfied with the training. Participants were asked about what they were most satisfied with during the online birth preparation training. Both the pregnant women and their spouses (33.3\% of the pregnant women, $31.1 \%$ of the spouses) stated that being together with different families and sharing their experiences made them happy, and also receiving counseling relieved the participants and reduced their stress $(28.9 \%$ of the pregnant women, $31.1 \%$ of the spouses).
The mean BAI score of the pregnant women before the training was $9.05 \pm 7.29$, and the mean BAI score of the fathers was 3.13 \pm 3.60 . Anxiety scores decreased after the education in both groups. After the training, the mean BAI score of the pregnant women was $5.56 \pm 5.38$ and the fathers was $2.02 \pm 2.49$ and the difference was statistically significant $(\mathrm{p}<0.05)$ (Table 8).

\section{Discussion}

Good mental health during pregnancy is important for maternal and fetal health. It is known that mental illnesses can affect the mood of the mother and cause negative consequences related to pregnancy and increase maternal and fetal morbidity and mortality rate in those who do not receive treatment (27). It is important to recognize and prevent psychosocial reactions as well as physiological reactions during pregnancy, to reduce their effects on maternal and child health and to improve preventive mental health services. Thus, psychological evaluation as well as physical evaluation during pregnancy follow-up is important for a holistic approach $(28,29)$. Psychosocial health and social support, which may affect the pregnant woman's adaptation processes to pregnancy, birth and parenthood, should have an important place in the nursing care of the pregnant woman and her family $(10,30)$. During prenatal follow-up, nurses and midwives often play the roles of educators and counselors to identify, protect and improve the psychosocial health status of pregnant women. It is important to evaluate the psychosocial health as well as physical health during the nursing and midwifery process, which includes the follow-up and care of the pregnant woman, to determine the effects of family, culture, religion and other factors during pregnancy, and to reveal the social support of prospective parents $(30,31)$.

We planned our study considering the necessity of pregnancy schools and provided pregnant women and their spouses pregnancy school online in safe home conditions. Our aims were to determine the opinions of pregnant women and their spouses about the COVID-19 process during the pandemic period, to create awareness about the process, to support pregnant women and their spouses with online pregnancy school trainings, and to reduce anxiety rates.

The amean age of the pregnant women participating in our study was $29.44 \pm 4.43$, the mean age of the spouses was $32.58 \pm 5.37$, and the mean duration of marriage was 3.01 1.91 years. Most of the participants received high school or higher education, did not have chronic illnesses, did not smoke and drink alcohol, and evaluated their mental state as good. $93.4 \%$ of the participants had social security and most (97.8\%) of them had nuclear family structure (Table 1).

Similar results have been reported in other studies conducted with pregnant women (32-34). In these studies, Özkan and Arslan (32) reported that $79 \%$ of the pregnant women were between 20-29, Tunç et al. (35) reported that $33 \%$ of the pregnant women were between 23-27, Demirbas et al. (36) reported that $56.2 \%$ of the pregnant women were between $18-29$ (36) and Ozcelik and Larch (33) reported that $56.5 \%$ of the pregnant 
Table 4. Distribution of the topics that the participants wanted to be included in online birth preparation training

\begin{tabular}{|c|c|c|c|c|c|c|c|c|}
\hline \multirow{3}{*}{ Topics Related to pregnancy } & \multicolumn{4}{|c|}{ Mother } & \multicolumn{4}{|c|}{ Father } \\
\hline & \multicolumn{2}{|c|}{ Necessary } & \multicolumn{2}{|c|}{ Unnecessary } & \multicolumn{2}{|c|}{ Necessary } & \multicolumn{2}{|c|}{ Unnecessary } \\
\hline & $\mathrm{N}$ & $\%$ & $\mathrm{~N}$ & $\%$ & $\mathrm{~N}$ & $\%$ & $\mathrm{~N}$ & $\%$ \\
\hline Nutrition & 39 & 86.7 & 6 & 13.3 & 45 & 100.0 & - & - \\
\hline Hygiene & 38 & 84.4 & 7 & 15.6 & 43 & 95.6 & 2 & 4.4 \\
\hline Excretory habits & 44 & 97.8 & 1 & 2.2 & 44 & 97.8 & 1 & 2.2 \\
\hline Perineum care & 45 & 100.0 & - & - & 45 & 100.0 & - & - \\
\hline Pregnancy follow-ups & 44 & 97.8 & 1 & 2.2 & 45 & 100.0 & - & - \\
\hline Infection control measures & 45 & 100.0 & - & - & 45 & 100.0 & - & - \\
\hline Physical activity and exercises & 42 & 93.3 & 3 & 6.7 & 45 & 100.0 & - & - \\
\hline Breastfeeding & 44 & 97.8 & 1 & 2.2 & 44 & 97.8 & 1 & 2.2 \\
\hline Bathing & 42 & 93.3 & 3 & 6.7 & 40 & 88.9 & 5 & 11.1 \\
\hline Babycare & 44 & 97.8 & 1 & 2.2 & 43 & 95.6 & 2 & 4.4 \\
\hline Dressing & 42 & 93.3 & 3 & 6.7 & 39 & 86.7 & 6 & 13.3 \\
\hline Sleep & 43 & 95.6 & 2 & 4.4 & 42 & 93.4 & 3 & 6.6 \\
\hline Burping & 44 & 97.8 & 1 & 2.2 & 44 & 97.8 & 1 & 2.2 \\
\hline Vaccination & 43 & 95.6 & 2 & 4.4 & 42 & 93.4 & 3 & 6.6 \\
\hline Routine controls & 43 & 95.6 & 2 & 4.4 & 43 & 95.6 & 2 & 4.4 \\
\hline
\end{tabular}

women were between 28-32 years old. In our study most of the participants received high school and higher education. In other studies conducted with pregnant women in Turkey, majority of women were primary school graduates $(2,9,12,15,37)$. The higher education level of the participants in our study compared to other studies was due to the fact that the participants who cared about pregnancy school training and wanted to receive education were included in our study. In addition, the presence of participants with a high level of education will be effective in their better adaptation to pregnancy process. In this study, $73.3 \%$ of the pregnant women were primipars, $93.4 \%$ of them got pregnant willingly, and most of them (91.2\%) attended to regular pregnancy controls (Tablo 2). The high education level of the participants was effective in the high rate of receiving antenatal care (ANC).

The rates of ANC varies in different countries (38). According to Turkey Demographic Health Survey, 90\% of women recieved 4 or more times antenatal care (39). Among similar field studies conducted in Turkey, all pregnant women in Burdur received ANC at least once, while $1.7 \%$ of pregnant women in Adiyaman, and $0.6 \%$ in Istanbul didn't to receive ANC from their obstetrist or primary care physician (40).
The opinions of the participants about the functioning of the pregnancy school are given in Table 3. Participants mostly (77.8\% of the pregnant women, and $82.2 \%$ of the fathers) considered themselves competent in pregnancy, birth, puerperium, and stated that suspending the birth preparation trainings during the pandemic period was not good $(62.2 \%$ of the pregnant women, $71.1 \%$ of the fathers). Most of them (95.6\% of the pregnant women, $100 \%$ of the fathers) wanted to get birth preparation training online.

Although birth is a natural process, women have significant fears about childbirth and prenatal training is required to cope with these fears $(41,42)$. In order to protect and improve psychosocial health, a nurse becomes an important member of the healthcare team that allows the pregnant women and her families to express their feelings and concerns, use positive coping strategies, and regulate family relationships during prenatal follow-up. In addition, it is among the duties of the nurse to determine the existing social support systems in this process and to ensure that the pregnant women and their families use them effectively $(30,31)$. Pregnancy schools have important roles in protecting and improving the psychosocial health of both pregnant women and their families. At first, pregnancy schools were opened to encourage normal birth, but later on prenatal, birth and postnatal 
Table 5. Participants' opinions on COVID-19 infection control measures

\begin{tabular}{|c|c|c|c|c|c|c|c|c|c|c|c|c|}
\hline \multirow{3}{*}{ Opinions } & \multicolumn{6}{|c|}{ Mother } & \multicolumn{6}{|c|}{ Father } \\
\hline & \multicolumn{2}{|c|}{ Yes } & \multicolumn{2}{|c|}{ Indecisive } & \multicolumn{2}{|l|}{ No } & \multicolumn{2}{|l|}{ Yes } & \multicolumn{2}{|c|}{ Indecisive } & \multicolumn{2}{|l|}{ No } \\
\hline & $\mathrm{N}$ & $\%$ & $\mathrm{~N}$ & $\%$ & $\mathrm{~N}$ & $\%$ & $\mathrm{~N}$ & $\%$ & $\mathrm{~N}$ & $\%$ & $\mathrm{~N}$ & $\%$ \\
\hline Do you know what a COVID infection is? & 42 & 93.3 & 3 & 6.7 & - & - & 42 & 93.3 & 3 & 6.7 & - & - \\
\hline Can COVID infection be prevented? & 31 & 68.9 & 13 & 28.9 & 1 & 2.2 & 37 & 82.2 & 7 & 15.6 & 1 & 2.2 \\
\hline $\begin{array}{l}\text { Is hand hygiene important to prevent } \\
\text { COVID infection? }\end{array}$ & 44 & 97.8 & 1 & 2.2 & - & - & 45 & 100.0 & - & - & - & - \\
\hline $\begin{array}{l}\text { Should hand sanitizer be used to prevent } \\
\text { COVID infection? }\end{array}$ & 36 & 80.0 & 7 & 15.6 & 2 & 4.4 & 41 & 91.1 & 3 & 6.7 & 1 & 2.2 \\
\hline $\begin{array}{l}\text { Should a mask be worn to protect against } \\
\text { COVID infection? }\end{array}$ & 40 & 88.9 & 5 & 11.1 & - & - & 44 & 97.8 & 1 & 2.2 & - & - \\
\hline $\begin{array}{l}\text { Do you think home isolation is important } \\
\text { to prevent COVID infection? }\end{array}$ & 42 & 93.3 & 2 & 4.4 & 1 & 2.2 & 45 & 100.0 & - & - & - & - \\
\hline $\begin{array}{l}\text { Do you know what social distance means } \\
\text { to protect from COVID infection? }\end{array}$ & 45 & 100.0 & - & - & - & - & 45 & 100.0 & - & - & - & - \\
\hline $\begin{array}{l}\text { Do you implement precautions to protect } \\
\text { against COVID infection during pregnancy? }\end{array}$ & 44 & 97.8 & 1 & 2.2 & - & - & 42 & 93.3 & 3 & 6.7 & - & - \\
\hline $\begin{array}{l}\text { Do you think you have enough information } \\
\text { about measures to protect against COVID } \\
\text { infection? }\end{array}$ & 39 & 86.7 & 6 & 13.3 & - & - & 36 & 80.0 & 3 & 6.7 & 6 & 13.3 \\
\hline $\begin{array}{l}\text { Can you apply social distance and isolation } \\
\text { rules in home conditions? }\end{array}$ & 35 & 77.8 & 4 & 8.9 & 6 & 13.3 & 36 & 80.0 & 3 & 6.7 & 6 & 13.3 \\
\hline $\begin{array}{l}\text { Do you know the precautions that your } \\
\text { relatives living at home should take for } \\
\text { infection control? }\end{array}$ & 42 & 93.3 & 3 & 6.7 & - & - & 41 & 91.1 & 1 & 2.2 & 3 & 6.7 \\
\hline Total & 45 & 100.0 & 45 & 100.0 & 45 & 100.0 & 45 & 100.0 & 45 & 100.0 & 45 & 100.0 \\
\hline
\end{tabular}

care, healthy lifestyle habits, and reducing anxiety and depression levels began to be addressed (31).

In this study, both the pregnant women and their spouses wanted all subjects related to pregnancy process and baby care to be included in their training process (Table 4). Previous studies stated that pregnancy schools aim to provide expectant mothers with knowledge and skills on issues related to pregnancy, birth and the postpartum period, normal labor, pain management, and adaptation to new roles (43). Our results were in accordance with the literature.

We also evaluated the opinions and concerns of the participants about the COVID-19 pandemic. Based on the opinions and training needs, online pregnancy schools werte planned. The participants were generally (93.3\% pregnant women, $93.3 \%$ fathers) knowledgeable about COVID-19 infection control measures and applied protection measures at high rates $(97.8 \%$ of the pregnant, $93.3 \%$ of the fathers). When the concerns of the participants about the pandemic period were evaluated, pregnant women mostly worried from not to have a spouse or a relative at birth (86.2\%), getting COVID-19 infection from healthcare workers $(82.2 \%)$, and experiencing pain with a mask $(82.2 \%)$. Concerns of the fathers were not being with their wives during birth (82.2\%), getting COVID-19 infection from another patient $(80 \%)$, or from healthcare workers $(75.6 \%)$ (Table 6).
CoVs are important human and animal pathogens. In February 2020, the World Health Organization identified COVID-19 disease, which stands for 2019 coronavirus disease. Coronavirus infection spread around the world, causing a pandemic. Its rapid spread, lack of treatment and fatal course make the effects of the virus important. The high mortality and morbidity of the disease increases the clinical importance of this infection. There is limited information about infection in pregnant women and it is recommended that management be done like non-pregnant women for now. Fetal distress and premature birth have been observed in some pregnant women. There is no evidence yet for mother-to-baby transmission. Isolation under appropriate conditions, effective control and management of infection, early mechanical ventilation in progressive respiratory problems, oxygen therapy, avoidance of excess fluid treatment, and strict fetal and uterine monitoring are required in pregnancy and delivery management. Management of suspected or infected pregnant women should be done by a multidisciplinary team $(20,44)$. The fact that the pandemic process is widespread and uncertain has increased the concerns of pregnant women and their families, especially in the risky group. During this period, it is important that all healthcare team members take a holistic role and activate support processes.

The status of the mother changes in the family and society with pregnancy and childbirth, she assumes new responsibilities and 
Table 6. Participants' concerns about COVID-19 Infection

\section{Concerns of mothers about COVID-19 infection}

I do not want to go to follow-ups just because I fear to get COVID-19 infection from hospitals

Have enough precautions been taken in the hospital where I am being followed up for the pregnancy? Are there any COVID-19 patients?

May I contract COVID-19 infection from healthcare workers?

My husband is working and I'm afraid he might bring home COVID-19

If I get COVID-19 infection during pregnancy, will my baby be harmed?

Even if I do not have an infection, is there a risk of transmission from another patient during or after birth in the hospital?

Do interventions increase in this period to accelerate birth?

I'm afraid of not getting physical support at birth

Not to have my husband or a relative with me during birth worries me.

Experiencing the pain with a mask worries me

Will they direct me for a planned cesarean instead of a normal delivery?

If I become COVID-19 positive, can I breastfeed my baby?

Who will take care of my baby if I am sick?

I will not be able to get support from elders after birth, I have fears about breastfeeding and baby care.

I am worried about going to the health institution for the vaccinations and control of my baby, how can I take precautions.

\section{Fathers' concerns about COVID-19 infection}

I do not want to take my wife to follow-ups just because we can catch COVID-19 infection from hospitals.

May I contract COVID-19 infection from healthcare workers?

I am working and I'm afraid I bring home COVID-19

Who cares for my family if I get COVID-19 disease?

If my wife gets COVID infection, will our baby be harmed?

Is there a risk my wife contracts COVID infection at a hospital during or after birth?

I am worried that I can't be with my wife during birth.

Will they direct me for a planned cesarean instead of a normal delivery?

If my wife becomes ill, who will take care of our baby?

We are afraid that we will not be able to get support from elders after birth

Total

COVID-19: Coronavirus disease-19

has to fulfill new roles. These mandatory roles and responsibilities that need to be fulfilled may lead to adaptation problems in some individuals. Also, pregnancy is an important time of psychosocial and developmental transition and adaptation. Adaptation to pregnancy and the changes it brings is perceived differently by every woman and family, and therefore different reactions and problems may arise in adaptation (45-47). Social support, spouse and marital harmony are of great importance in adaptation to pregnancy. Social support, which is defined as the total support provided by family members, friends and other social relationships, has positive effects on physical health and

\begin{tabular}{|c|c|c|c|c|c|}
\hline \multicolumn{2}{|l|}{ Yes } & \multicolumn{2}{|c|}{ Unstable } & \multicolumn{2}{|l|}{ No } \\
\hline$N$ & $\%$ & $\mathrm{~N}$ & $\%$ & $\mathrm{~N}$ & $\%$ \\
\hline 29 & 64.4 & 10 & 22.2 & 6 & 15.3 \\
\hline 25 & 55.6 & 17 & 37.8 & 3 & 6.7 \\
\hline 37 & 82.2 & 8 & 17.8 & - & - \\
\hline 22 & 48.9 & 9 & 20.0 & 14 & 31.1 \\
\hline 28 & 62.2 & 11 & 24.4 & 6 & 13.3 \\
\hline 35 & 77.8 & 10 & 22.2 & - & - \\
\hline 25 & 55.6 & 14 & 31.1 & 6 & 13.3 \\
\hline 30 & 66.7 & 8 & 17.8 & 7 & 15.5 \\
\hline 39 & 86.2 & 6 & 13.3 & - & - \\
\hline 37 & 82.2 & 3 & 6.7 & 5 & 11.1 \\
\hline 26 & 57.8 & 9 & 20.0 & 10 & 22.2 \\
\hline 33 & 73.3 & 8 & 17.8 & 7 & 6.9 \\
\hline 29 & 64.4 & 10 & 22.2 & 6 & 13.3 \\
\hline 31 & 68.9 & 2 & 4.4 & 12 & 26.7 \\
\hline 36 & 80.0 & 5 & 11.1 & 4 & 8.9 \\
\hline \multicolumn{2}{|c|}{ Yes } & \multicolumn{2}{|c|}{ Indecisive } & \multicolumn{2}{|l|}{ No } \\
\hline $\mathbf{N}$ & $\%$ & $\mathbf{N}$ & $\%$ & $\mathbf{N}$ & $\%$ \\
\hline 21 & 46.7 & 12 & 26.7 & 12 & 26.7 \\
\hline 34 & 75.6 & 10 & 22.2 & 1 & 2.2 \\
\hline 30 & 66.7 & 5 & 11.1 & 10 & 22.2 \\
\hline 20 & 44.4 & 12 & 26.7 & 13 & 28.9 \\
\hline 29 & 64.4 & 9 & 20.0 & 7 & 15.6 \\
\hline 36 & 80.0 & 8 & 17.8 & 1 & 2.2 \\
\hline 37 & 82.2 & 6 & 13.3 & 2 & 4.4 \\
\hline 15 & 33.3 & 14 & 31.1 & 16 & 35.6 \\
\hline 18 & 40.0 & 13 & 28.9 & 14 & 26.7 \\
\hline 20 & 44.4 & 8 & 17.8 & 17 & 37.8 \\
\hline 45 & 100.0 & 45 & 100.0 & 45 & 100.0 \\
\hline
\end{tabular}

well-being (48) because social support systems make it easier to adapt to new situations (49). Considering that psychosocial and developmental transition and adaptation problems are experienced even during normal pregnancy, adjustment problems, anxiety, and increased need for social support may be expected during pandemic process. In our study, as expected pregnant women and their spouses had high anxiety rates regarding the COVID-19 pandemic process and expressed their needs in this regard.

The prevalence of psychosocial health problems such as depression, anxiety and stress is high during pregnancy and 
Table 7. Participants' opinions on online birth preparation trainings

\begin{tabular}{|c|c|c|c|c|}
\hline \multicolumn{5}{|l|}{ Opinions } \\
\hline \multicolumn{2}{|c|}{$\begin{array}{l}\text { Did the online birth } \\
\text { preparation training meet your } \\
\text { expectations? }\end{array}$} & \multicolumn{3}{|c|}{$\begin{array}{l}\text { Yes, I was very pleased } \\
\text { It met my expectations moderat }\end{array}$} \\
\hline & & \multicolumn{3}{|c|}{ I was able to get the informatior } \\
\hline \multirow{2}{*}{\multicolumn{2}{|c|}{$\begin{array}{l}\text { On which subject online birth } \\
\text { preparation training pleased } \\
\text { you the most? }\end{array}$}} & \multicolumn{3}{|c|}{ Counseling relaxed me, my stres } \\
\hline & & \multicolumn{3}{|c|}{$\begin{array}{l}\text { It made me happy to be togethe } \\
\text { share experiences. }\end{array}$} \\
\hline & & \multicolumn{3}{|c|}{ I learned more about COVID infe } \\
\hline & & \multicolumn{3}{|c|}{ Other } \\
\hline \multicolumn{5}{|l|}{ Total } \\
\hline \multicolumn{5}{|l|}{ COVID: Coronavirus disease } \\
\hline \multicolumn{5}{|c|}{$\begin{array}{l}\text { Table 8. Comparison of participants' mean beck anxiety } \\
\text { scale scores before and after training }\end{array}$} \\
\hline \multicolumn{3}{|c|}{ Features } & Mean \pm SD & $p$ \\
\hline \multirow[b]{2}{*}{ Mothers' BAI scores } & \multirow{2}{*}{\multicolumn{2}{|c|}{$\begin{array}{l}\text { Before training } \\
\text { After training }\end{array}$}} & $9.05 \pm 7.29$ & \\
\hline & & & $5.56 \pm 5.38$ & \\
\hline \multirow{2}{*}{ Fathers' BAI scores } & \multirow{2}{*}{\multicolumn{2}{|c|}{$\begin{array}{l}\text { Before traning } \\
\text { After training }\end{array}$}} & $3.13 \pm 3.60$ & \\
\hline & & & $2.02 \pm 2.49$ & 0.000 \\
\hline
\end{tabular}

these psychosocial health problems can negatively affect the health of both pregnant women and babies $(50,51)$. In a study that wanted to draw attention to the psychosocial health status during pregnancy, the frequency of antenatal anxiety was $20.6 \%$ and there was a relationship between education level and anxiety prevalence (52). As can be seen in the study by Agostini et al. (53), another factor that is related to the occurrence of mental problems during pregnancy which has an important role in pregnancy, and significantly affects psychosocial health, is the level of social support the woman receives (54). Elsenbruch et al. (55) found that pregnant women who did not have sufficient social support had high depressive symptoms and low quality of life. Evaluation of the studies on social support during pregnancy revealed that, another factor that can turn pregnancy into a risky period is the lack of social support systems. In addition, it is stated that the lack of social support during pregnancy negatively affects the health of the mother, fetus, and baby $(33,56)$. A study performed by Şen and Şirin (31) with pregnant women who had preterm labor found that adequate social support decreased the rate of depression and anxiety in women, and positively affected the course of pregnancy and the health of the baby.

The opinions of the pregnant women and their spouses about the education were received after online pregnancy school. The participants were very satisfied with the training provided, they stated that especially being together with different families, sharing experiences online made them happy, and getting consultancy reduced their stress (Table 7).

Physiological and psychological changes that occur in a woman's body during pregnancy can affect not only the mother but also the people around her, her husband, family, and friends in various ways. Labor, which is the transition period for being a parent, is a temporary situation that affects both parents (17). In a study conducted with 390 women in the prenatal period, women who received information about pregnancy were more compatible with pregnancy and motherhood. The study found that women's adjustment to pregnancy was affected by many variables and prenatal care is of great importance in achieving this adjustment (36).

Previous literature reported that there may be a relationship between prenatal distress levels and the health status of the pregnant $(57,58)$ and the first pregnancy $(59)$. The training women received at the pregnancy school benefited both during pregnancy and the birth process (coping with labor pain, decreased birth fears) $(60,61)$, facilitated the adjustment to pregnancy and motherhood, positively affected motivation (62), pregnant women were mostly satisfied with these training, and their level of knowledge increased significantly (63). Literature suggests that pregnancy school program has significant contributions to the pregnancy, birth, and postpartum period, and increases the adaptation of women to pregnancy. We also found that online pregnancy school, which was provided in accordance with the literature, pleased the participants, increased their awareness, and decreased stress rates.

In our study, before the training, the mean BAI score of the pregnant women was 9.05 \pm 7.29 (mild anxiety), and the mean BAI for their spouses was $3.13 \pm 3.60$ (minimal anxiety), and anxiety scores decreased after the education in both groups. After the education, the mean BAI score of the pregnant women was $5.56 \pm 5.38$ (minimal level of anxiety), and the mean BAI for their spouses was $2.02 \pm 2.49$ (minimal level of anxiety) and the difference between pre and post-training values was statistically significant $(\mathrm{p}<0.05)$ (Table 8$)$.

Population-based studies found that during pregnancy the prevalence of affective disorders was $70 \%$, anxiety was $15-29 \%$, and depression was $17-18 \%$ (64). Studies investigating the prevalence of depression during pregnancy in different cultures often found similar results. Lancaster et al. (49) found 18\%, a 
Hungarian study found $17.9 \%$, a study from the USA found 30-38\%, and a Latin American study found approximately 30\% (64). Reports from Turkey found the prevalence of anxiety as 12$34 \%$ and the prevalence of depression as $19-53 \%$ (65-68).

Studies investigating the prevalence of psychological distress during pregnancy demonstrated that $13-25 \%$ of women in developed countries experience clinically significant psychological distress attacks, especially depression or anxiety disorders $(69,70)$. Another study found the prevalence of distress in pregnancy between $41.7 \%$ and $51 \%$ (71). Studies on this topic from Turkey are limited. Karacam and Ancel found the prevalence of depressive symptoms in pregnancy as $27.3 \%$ (72). Golbaşı et al. (73) used the Edinburgh Postnatal Depression Scale (EPDS) and found the prevalence of depressive symptoms during pregnancy as $28.6 \%$. Lee et al. found anxiety in $54 \%$ of pregnant women and depression in $37.1 \%$ (74). Studies that investigated the prevalence of anxiety and depression in Turkey and in various cultures gave similar results $(16,75)$.

In our study, anxiety level was mild in pregnant women and minimal in their spouses. With the training program and social support process, the anxiety levels decreased in both groups, and the difference was statistically significant. With these results H1 hypothesis, "Online pregnancy school education has a positive effect on reducing the anxiety rates of pregnant women and their partners" was accepted.

It is very important for a healthy mother, baby, and family that psychosocial health, which may affect the processes of pregnancy, birth, postpartum, and parenting is addressed by nurses. Nurses are the members of the healthcare team in the most appropriate position to provide opportunities for the pregnant woman and her family by preparing an environment for expressing feelings and concerns during pregnancy, using positive coping strategies, organizing family relationships, and activating existing social support systems effectively. In this adaptation process, nurses frequently support the needs of pregnant women and their families with their educator and counselor roles. In order to protect and improve the health of the woman and her family with a holistic approach in the nursing process during the care of the pregnant woman, it is important to determine the effects of psychosocial health on pregnancy experience and the support that prospective parents receive from their social environment $(24,28,30,31)$. In this context, nurses may activate the existing social support of pregnant women and prevent possible psychosocial health problems.

\section{Conclusion}

We found that the participants were generally knowledgeable about COVID-19 infection control measures and applied protection measures. During the pandemic, the most common worries of the pregnant women and their spouses were not to have a spouse or a relative at birth, and contracting COVID-19 from healthcare workers or other patients $(p<0.05)$. We found that the changes experienced during pregnancy and the pandemic period increased the anxiety levels and supportive needs of pregnant women and their spouses.
Pregnant women need support to maintain their balance during pregnancy and birth. Health personnel who will provide this assistance must be competent in the psychological and physiological changes that will occur during pregnancy and must have developed communication skills. Together with the pregnant woman, the family and especially her husband should be educated about the physiological and psychological aspects of pregnancy. National and international support groups and antenatal mental health units should be established to provide education, support, and professional assistance to women and their spouses. For this reason, anxiety symptoms should be taken seriously, evaluated well, and pregnant women and their families should be supported with training and holistic approaches, especially during periods of radical changes such as pandemic periods.

\section{Ethics}

Ethics Committee Approval: Institutional permission from the institution where the research was conducted and approval from the ethics committee was obtained.

Informed Consent: Written consent was taken after the pregnant women participating in the study and their spouses were informed about the purpose of the study and it was explained that the obtained information would only be used for this study.

Peer-review: Externally peer reviewed.

\section{Authorship Contributions}

Surgical and Medical Practices: Y.D.M., Ö.K., Concept: Y.D.M., Ö.K., Design: Y.D.M., Ö.K., A.S., Data Collection or Processing: Ö.K., A.S., Analysis or Interpretation: Y.D.M., Literature Search: Y.D.M., Writing: Y.D.M.

Conflict of Interest: No conflict of interest was declared by the authors.

Financial Disclosure: This work was supported by Gilead Sciences.

\section{References}

1. Vırıt O, Akbaş E, Savaş HA, Sertbaş G, Kandemir H. Association between the level of depression and anxiety with social support in pregnancy. Arch Neuropsychiatry 2008;45:9-13.

2. Marakoğlu K, Şahsıvar MŞ. Depression in Pregnancy. Turkiye Klinikleri J Med Sci 2008;28:525-32.

3. Taner Y. Çocuk, ergen ve erişkinlerde anksiyete bozuklukları. İçinde: Işık E, editör. Golden Print;2006.

4. No authors listed. Women and anxiety disorder:Implications for diagnosis and treatment. CNS Spectr 2004; 9:1-16.

5. Josefsson A, Berg G, Nordin C, Sydsjö G. Prevalence of depressive symptoms in late pregnancy and postpartum. Acta Obstet Gynecol Scand 2001;80:251-5.

6. Evans J, Heron J, Francomb H, Oke S, Golding J. Cohort study of depressed mood during pregnancy and after childbirth. BMJ 2001;323:257-60. 
7. Andersson L, Sundström-Poromaa I, Wulff M, Aström M, Bixo M. Depression and anxiety during pregnancy and six months postpartum: a follow-up study. Acta Obstet Gynecol Scand 2006;85:937-44.

8. Özkan S. Psikiyatrik Tip, Konsültasyon-Liyezon Psikiyatri Kitabı. 1.Baskı. İstanbul: Roche; 1993;201-9.

9. Cebeci SA, Aydemir Ç, Göka E. Puerperal dönemde depresyon semptom prevalansı, obstetrik risk faktörleri, kaygı düzeyi ve sosyal destek ile ilişkisi. Kriz Dergisi 2002;10:11-8.

10. Yıldız H. Gebelikte psikososyal sağlığı değerlendirme ölçeği geliştirme çalışması. Maltepe Üniversitesi Hemşirelik Bilim ve Sanatı Dergisi 2011;4:63-74.

11. Mergen H, Ongel K. Factors associated with depression among Turkish faculty of education freshmen by Beck depression InventoryII-Turkish. Zdravniski Vestnik 2009;78:548-54.

12. Çakırer N, Çalışkan Z. Nevşehir ili Ağıllı köyünde gebelik, doğum ve lohusalığa ilişkin geleneksel inanç ve uygulamalar. TAF Preventive Medicine Bulletin 2010;9:343-8.

13. Davis DK. Myles midwifery a textbook for midwives. In: Henderson C, Macdonald S. 13th ed. London: Elsevier Limited; 2004.

14. Crawford J. Myles text for midwives. In: Fraser DM, Cooper MA, editors. 15th ed. London: Elsevier Limited; 2009.p.81-100.

15. Okumuş H, Yenal K, Ozan YD, Öztürk E. Ülkemizde doğuma hazırlık sınıflarına ilişkin yapılan bilimsel çalışmalar: Literatür derlemesi. Turkiye Klinikleri J Obstet Womens Health Dis NursSpecial Topics 2015;1:16-24.

16. Caliskan D, Oncu B, Kose K, Ocaktan ME, Ozdemir O. Depression scores and associated factors in pregnant women: A community based study in Turkey. J Psychosom Obstet Gynecol 2007;28:195-200.

17. Orr ST, Blazer DG, James SA, Reiter JP. Depressive symptoms and indicators of maternal health status during pregnancy. J Womens Health (Larchmt) 2007;16:535-42.

18. Alberque C, Bianchi-Demicheli F, Andreoli A, Epiney M, Irion O. Dépression grave pendant la grossesse: que faire? Management of severe antepartum depression: an update. Rev Med Suisse 2008;4:392-7.

19. Cornelius MD, Goldschmidt L, DeGenna N, Day NL. Smoking during teenage pregnancies: Effects on behavioral problems in offspring. Nicotine Tob Res 2007;9:739-50.

20. Mendilcioğlu İ. Gebelikte coronavirüs enfeksiyonu (COVID-19) hakkında görüş, Türkiye Maternal Fetal Tıp ve Perinatoloji Derneği Yayını; 2020.

21. Fullerton JT, Thompson JB, Severino R; International Confederation of Midwives. The international confederation of midwives essential competencies for basic midwifery practice. an update study: 20092010. Midwifery 2011;27:399-408.

22. Seefat-van Teeffelen A, Nieuwenhuijze M, Korstjens I. Women want proactive psychosocial support from midwives during transition to motherhood: A qualitative study. Midwifery 2011;27:122-7.

23. Hopkins J, Clarke D, Cross W. Inside stories: Maternal representations of first time mothers from pre-pregnancy to early pregnancy. Women Birth 2014;27:26-30.

24. Gönenç İM, Çakırer Çalbayram N. Gebelerin, gebe okulu programı hakkındaki görüşleri ve eğitim sonrası deneyimleri. Journal of Human Sciences 2017;14:1609-20.
25. Dağlar G, Bilgic D, Koc S, Yaprak B, Coskun P. Anxiety and depression levels of women's pre and post-labor stage and influencing factors. Innovative Journal of Medical and Health Science 2016;6:114-20.

26. Ulusoy M, Şahin NH, Erkmen H. Turkish version of the Beck Anxiety Inventory: Psychometric properties. J Cogn Psychother 1998;12:163-72.

27. Matthey S. Assessing for psychosocial morbidity in pregnant women. CMAJ 2005;173:267-9.

28. Kuğu N, Akyüz G. Gebelikte ruhsal durum. C.Ü.Tıp Fakültesi Dergisi 2001;23:61-4.

29. Midmer D, Bryanton J, Brown R. Assessing antenatal psychosocial health. Randomized controlled trial of two versions of the ALPHA form. Can Fam Physician 2004;50:80-7.

30. Coşar F, Demirci N. Lamaze felsefesine dayalı doğuma hazırlık eğitiminin doğum algısı ve doğuma uyum sürecine etkisi. Süleyman Demirel Üniversitesi Sağlık Enstitüsü Dergisi 2012;3:18-30.

31. Şen E, Şirin A. Preterm eylem tanısı alan gebelerin kaygı, depresyon ve algılanan sosyal destek düzeyini etkileyen faktörler. Gaziantep Tip Dergisi 2013;19:159-63.

32. Özkan A, Arslan H. Gebeliğe karar verme, fizyolojik yakınmaları algılama ve eğitim gereksinimleri. Zeynep Kamil Tıp Bülteni 2007;38:155-61.

33. Mermer G, Bilge A, Yücel U, Çeber E. Gebelik ve doğum sonrası dönemde sosyal destek algısı düzeylerinin incelenmesi, Psikiyatri Hemşireliği Dergisi 2010;1:71-6.

34. Özçelik G, Karaçam Z. Gebelikte sık karşılaşılan yakınmalar, fiziksel, ruhsal ve cinsel sağlık sorunları, risk faktörleri ve yaşam kalitesi ile ilişkileri. Ege Üniversitesi Hemşirelik Fakültesi Dergisi 2014;30:1-18.

35. Tunç S, Yenicesu O, Çakar E, Özcan H, Pekçetin S, Danışman $\mathrm{N}$. Antenatal dönemde anksiyete ve depresyonun görülme sıklığı ve ilişkili faktörler. Jinekoloji-Obstetrik ve Neonatoloji Tıp Dergisi 2012;9:1431-35.

36. Demirbaş H, Kadığlu H. Prenatal dönemdeki kadınların gebeliğe uyumu ve ilişkili faktörler. Marmara Üniversitesi Sağlık Bilimleri Enstitüsü Dergisi 2014;4:200-6.

37. Yenal K, Okumuş H, Sevil Ü. Web ortamında interaktif-antenatal danışmanlık ile gebeliğe ilişkin bilgi gereksinimlerinin incelenmesi. Dokuz Eylül Üniversitesi Hemşirelik Yüksekokulu Elektronik Dergisi 2010;3:9-14

38. Sütlü S, Çatak B, Kılınç AS, Taşdemir AB, Dinç M, Ayaş H. Doğum öncesi bakımın neresindeyiz? Toplum tabanlı bir araştırma. Sted 2012;2:264-70.

39. Hacettepe Üniversitesi Nüfus Etütleri Enstitüsü. Türkiye'de Doğurganlık, Üreme Sağlığı ve Yaşlılık, 2018 Türkiye Nüfus ve Sağlık Araştırması İleri Analiz Çalışması, Hacettepe Üniversitesi Nüfus Etütleri Enstitüsü, Sağlık Bakanlığı Ana Çocuk Sağlığı ve Aile Planlaması Genel Müdürlüğü, Başbakanlık Devlet Planlama Teşkilatı Müsteşarlığı ve TÜBİTAK, Ankara.

40. Çatak B, İkiışık H, Kartal SB, Öner C, Uluç HH, Seğmen Ö. İstanbul'da doğum öncesi bakım hizmetlerinin değerlendirilmesi: Toplum tabanlı bir araştırma. Perinatoloji Dergisi 2012;20:126-34.

41. Serçekuş P, Yenal K. Doğuma hazırlık sınıflarının Türkiye’deki gelişimi. Turkiye Klinikleri J Obstet Womens Health Dis NursSpecial Topics 2015;1:33-5. 
42. Bailey JM, Crane P, Nugent CE. Childbirth education and birth plans. Obstet Gynecol Clin North Am 2008;35:497-509.

43. T.C. Sağlık Bakanlığı Türkiye halk sağlı̆̆ı kurumu kadın ve üreme sağlığı daire başkanlığı. Gebe bilgilendirme sınıfı eğitimci kitabı 2013. Ankara: Türkiye Halk Sağlı̆̆ı Kurumu Kadın ve Üreme Sağlığı Daire Başkanlığı, 2013.

44. Köse A, Cevrioğlu Ö. COVID-19 ve gebelik. J Biotechnol and Strategic Health Res 2020;10-3.

45. Demiryay A. Gebe kadınların algıladıkları fiziksel ve emosyonel yakınmalar. Yayınlanmamış Yüksek Lisans Tezi. Afyon Kocatepe Üniversitesi Sağlık Bilimleri Enstitüsü, Afyon, Türkiye. 2006.

46. Yanıkkerem E, Altıparmak S, Karadeniz G. Gebelikte yaşanan fiziksel sağlık sorunlarının incelenmesi. Aile ve Toplum, Eğitim-Kültür ve Araştırma Dergisi 2006;3:35-42.

47. AWHONN. The role of the nurse in postpartum mood and anxiety disorders. An the Association of Women's Health, Obstetric and Neonatal Nurses. Symposium; 2013.

48. Faulkner M, Davies S. Social support in the healthcare setting: the role of volunteers. Health Soc Care Community 2005;1:38-45.

49. Özkan S, Sevil Ü. Doğum sonrası fonksiyonel durum envanterinin geçerlilik güvenilirlik çalışması. TSK Koruyucu Hekimlik Bülteni 2007;6:199-208.

50. Lancaster CA, Gold KJ, Flynn HA, Yoo H, Marcus SM, Davis MM. Risk factors for depressive symptoms during pregnancy: A systematic review. Am J Obstet Gynecol 2010;202:5-14.

51. Carolan-Olah M, Barry M. Antenatal stress: an Irish case study. Midwifery 2014;30:310-6.

52. Kang YT, Yao Y, Dou J, Guo X, Li SY, Zhao CN, et al. Prevalence and risk factors of maternal anxiety in late pregnancy in China. Int J Environ Res Public Health 2016;13:468.

53. Agostini F, Neri E, Salvatori P, Dellabartola S, Bozicevic L, Monti F. Antenatal depressive symptoms associated with specific life events and sources of social support among Italian women. Matern Child Health J 2015;19:1131-41.

54. Maharlouei N. The importance of social support during pregnancy. Women's Health Bull 2016;3:34991.

55. Isenbruch S, Benson S, Rücke M, Rose M, Dudenhausen J, PincusKnackstedt MK, et al. Social support during pregnancy: Effects on maternal depressive symptoms, smoking and pregnancy outcome. Hum Reprod 2007;22:869-77.

56. Clements AD, Fletcher TR, Childress LD, Montgomery RA, Bailey BA. Social support, religious commitment, and depressive symptoms in pregnant and postpartum women. Journal of Reproductive and Infant Psycholocy 2016;34:247-59.

57. Kaplan S, Bahar A, Sertbaş G. Gebelerde doğum öncesi ve doğum sonrası dönemlerde durumluk kaygı düzeylerinin incelenmesi. Atatürk Üniversitesi Hemşirelik Yüksekokulu Dergisi 2007;10:113-21.

58. Akbaş E, Vırıt O, Kalenderoğlu A, Savaş HA, Sertbaş G. Gebelikte sosyodemografik değişkenlerin kaygı ve depresyon düzeyleriyle ilişkisi. Arch Neuropsychiatry 2008;45:85-91.

59. Lobel M, DeVincent CJ, Kaminer A, Meyer BA. The impact of prenatal maternal stress and optimistic disposition on birth outcomes in medically high-risk women. Health Psychol 2000;19:544-53.
60. Yüksel B, Seven A, Yıldız Y, Gözükara İ, Kucur SK, Polat M, et al. Evaluation of the factors affecting pain perception of the patients before and after vaginal and cesarean delivery. Turkish Journal of Clinics and Laboratory 2015;6:116-20.

61. Fabian HM, Rådestad IJ, Waldenström U. Childbirth and parenthood education classes in Sweden. Women's opinion and possible outcomes. Acta Obstet Gynecol Scand 2005;84:436-43.

62. Oh HE, Sim GS, Kim JS. The effects of prenatal education on primiparas perception of delivery experience, self-confidence and satisfaction in maternal role performance. Korean J Women Health Nurs 2002;8:268-77.

63. Gagnon AJ, Sandall J. Individual or group antenatal education for childbirth or parenthood, or both. Cochrane Database Syst Rev 2007:CD002869.

64. Ali NS, Azam IS, Ali BS, Tabbusum G, Moin SS. Frequency and associated factors for anxiety and depression in pregnant women: A hospital-based cross-sectional study. Scientific WorldJournal 2012;2012:653098.

65. Yılmaz SD, Beji NK. Gebelerin stresle başa çıkma, depresyon ve prenatal bağlanma düzeyleri ve bunları etkileyen faktörler. Genel Tıp Dergisi 2010;20:99-108

66. Tekgöz I, Sunay D, Çaylan A, Kısa C. Gebeliğin son 3 ayında anksiyete bozukluğu ve ilişkili faktörlerin değerlendirilmesi. Türk Aile Hekimliği Dergisi 2009;13:132-36.

67. Yücel P, Çayır Y, Yücel M. Birinci trimester gebelerde depresyon ve anksiyete bozukluğu. Klinik Psikyatri 2013;16:83-7.

68. Arslan B, Arslan A, Kara S ve Öngel K, Mungan MT. Gebelik anksiyete ve depresyonunda risk faktörleri: 452 olguda değerlendirme. Tepecik Eğitim Hastanesi Dergisi 2011;21:79-84.

69. Priest SR, Henderson J, Evans SF, Hagan R. Stress debriefing after childbirth: a randomised controlled trial. Med J Aust 2003;178:542-5.

70. Gavin NI, Gaynes BN, Lohr KN, Meltzer-Brody S, Gartlehner G, Swinson T. Perinatal depression: A systematic review of prevalence and incidence. Obstet Gynecol 2005;106:1071-83.

71. Weidner K. Effects of an early intervention on perceived stress and diurnal cortisol in pregnant women with elevated stress, anxiety, and depressive symptomatology. J Psychosom Obstet Gynaecol 2012;33:162-70.

72. Karaçam Z, Ançel G. Depression, anxiety and influencing factors in pregnancy: A study in a Turkish population. Midwifery 2009;25:34456.

73. Gölbaşı Z, Kelleci M, Kısacık G. Gebelikte depresif belirtiler: Prevelans ve risk faktörlerine ilişkin bir çalışma. 5. Uluslar Arası Üreme Sağlığı ve Aile Planlaması Kongresi Özet Kitabı, 19-22 Nisan Ankara: 2007:255.

74. Lee AM, Lam SK, Sze Mun Lau SM, Chong CS, Chui HW, Fong DY. Prevalence, course, and risk factors for antenatal anxiety and depression. Obstet Gynecol 2007;110:1102-12.

75. Felice E, Saliba J, Grech V, Cox J. Prevalence rates and psychosocial characteristics associated with depression in pregnancy and postpartum in Maltese women. J Affect Disord 2004;82:297-301. 